ELEखण

\title{
RIADENIE LUDSKÝCH ZDROJOV V MARKETINGOVEJ A EVENTOVEJ AGENTÚRE V KONTEXTE MODELU 5P
}

\author{
Monika Ďugelová ${ }^{1}$ - Mariana Strenitzerová ${ }^{2}$ - Mária Šubíková
}

\begin{abstract}
Schuler's 5P model of strategic human resource management moulds various human resource activities with strategic needs. The purpose of our paper is to show the possibilities of usage the 5P model in marketing and event agency.

Keywords: strategic human resource management, 5P model, strategic vision, philosophy, policy of human resource managment

\section{Úvod}

Ciel'avedomé využívanie l’udského kapitálu je základom rozvoja podniku, ked’že zamestnanci, ich poznatky a schopnosti tvoria jej najcennejšie imanie. Podnik by mal zamerat' svoju pozornost' na zamestnancov a riešit' problémy nie operatívne, ale strategicky plánovat' ich optimálne využívanie a rozvoj ich schopností. K tomuto ciel'u slúži strategické riadenie l’udských zdrojov, ktoré nadväzuje na samotnú podnikovú stratégiu. Hlavnou úlohou podnikovej stratégie je nachádzat' nové možnosti a cesty budúceho rozvoja organizácie v rýchlo sa meniacich podmienkach trhového prostredia, v ktorom pôsobí. Úlohou strategického riadenia l'udských zdrojov je teda podporit' organizáciu na ceste k rozvoju prostredníctvom dlhodobého prístupu k hlavnej konkurenčnej výhode, l'udskému potenciálu.
\end{abstract}

\section{Teoretické východiská}

Pojem stratégia sa najskôr uplatňoval vo vojenskej terminológii, ale v priebehu 20. storočia prenikol aj do sveta podnikania a stal sa jeho neoddelitel'nou súčast'ou. Stratégia určuje základné dlhodobé ciele podniku, spôsoby ich dosiahnutia a alokáciu zdrojov, ktoré sú nevyhnutné na dosiahnutie týchto ciel'ov. [1]

Strategické riadenie l'udských zdrojov podl'a Čihovskej možno považovat' za prístup $\mathrm{k}$ riešeniu dlhodobých problémov týkajúcich sa l'udského kapitálu, pričom jeho hlavnými ciel'mi sú [2]:

- zabezpečit' integráciu stratégie so strategickými ciel'mi podniku,

- zabezpečit' zhodu politiky riadenia l'udských zdrojov s politikami jednotlivých oblastí a úrovní podniku,

\footnotetext{
${ }^{1}$ Ing. Monika Ďugelová, Žilinská univerzita v Žiline, Fakulta prevádzky a ekonomiky dopravy a spojov, Katedra spojov, Univerzitná 1, 01026 Žilina, tel. 041 5133145, e-mail: monika.dugelova@fpedas.uniza.sk

2 doc. Ing. Mariana Strenitzerová, PhD., Žilinská Univerzita v Žiline, Fakulta prevádzky a ekonomiky dopravy a spojov, Katedra spojov, Univerzitná 1, 01026 Žilina, Slovenská republika tel. 00421-041-5133 131, fax 00421-041-5655 615, e-mail: Mariana.Strenitzerova@fpedas.uniza.sk
} 
- zabezpečit', aby sa prínosy riadenia l'udských zdrojov využívali v celom systéme riadenia podniku.

V praxi sa najčastejšie uplatňuje „Model 5P“ strategického riadenia l'udských zdrojov, ktorý obsahuje nasledovné kroky [3]:

1. Stratégia podniku - určuje postupy a činnosti potrebné pri splnení vytýčených ciel'ov.

2. Analýza vonkajšieho a vnútorného prostredia - vonkajšie prostredie ovplyvňujú predovšetkým ekonomické podmienky, konkurenčná štruktúra, trh práce, demografické a legislatívne podmienky. Vnútorné prostredie podniku ovplyvňujú finančný kapitál, l'udský kapitál, inovácie, technika a technológia.

3. Strategické potreby podnikania - možno ich identifikovat' prostredníctvom otázky: „Čo je potrebné urobit' v oblasti riadenia l'udských zdrojov, aby podnik mohol uskutočnit' vybranú stratégiu?"

4. Filozofia riadenia l'udských zdrojov - poukazuje na to, ako vrcholové vedenie vníma zamestnancov organizácie v súvislosti s celkovou filozofiou podniku.

5. Politika riadenia l'udských zdrojov - definuje určité hodnoty, ktorými sa usmerňuje správanie zamestnancov pri dosahovaní ciel'ov podniku.

6. Programy riadenia l'udských zdrojov - sú vyjadrené ako stratégie riadenia l'udských zdrojov, zahŕňajú metódy, zdroje a časové ohraničenia realizácie stanovených politík.

7. Praktiky a procesy riadenia l'udských zdrojov - bývajú zakomponované do programov riadenia l'udských zdrojov, predstavujú konkrétne aktivity a postupy.

\section{Ciele a použitá metodika}

Ciel’om príspevku v nadväznosti na teoretické východiská je návrh riadenia l’udských zdrojov vo vybranej marketingovej agentúre podl'a modelu 5P. Pri dosahovaní ciel'a príspevku je použitá metóda osobného expertného interview a dotazníka.

Uskutočnenie výskumnej metódy interview predstavuje asymetrickú situáciu, pri ktorej výskumník vedie rozhovor a kladie otázky a respondent na otázky odpovedá. Odpovede si výskumník zaznamenáva a neskôr ich vyhodnotí. Interview umožňuje zachytit' nielen fakty, ale i hlbšie preniknút' do motívov a postojov respondentov, možno pri ňom sledovat' aj vonkajšie reakcie respondenta a podl'a nich usmerňovat' d'alší priebeh interview.

Dotazník patrí medzi jednu z najčastejšie používaných metód vo výskume. Používa sa v spoločenských vedách na hromadné a rýchle zist'ovanie faktov, názorov, postojov, preferencií, hodnôt, motívov, potrieb, záujmov a i.

\section{Výsledky a ich diskusia}

Model 5P strategického riadenia l'udských zdrojov umožňuje prostredníctvom na seba nadväzujúcich krokov definovat' stratégiu riadenia l'udských zdrojov a uvedomit' si tak budúcnost' podniku a jeho najcennejšieho imania. Jednotlivé kroky modelu a ich riešenie boli diskutované počas interview s majitel'mi agentúry, ako aj s líniovými manažérmi, ktorí sa podiel'ajú na riadení zamestnancov. Názory zamestnancov na vzdelávací proces boli zist'ované počas dotazníka, na ktorý odpovedali všetci zamestnanci. Ciel'om dotazníka bolo zistit' spokojnost' zamestnancov s úrovňou súčasného vzdelávacieho procesu.

Podnik má v súčasnosti definovanú víziu, politiku a strategické ciele podniku. $\mathrm{V}$ nadväznosti na dané aspekty stratégie podniku navrhneme podl'a krokov modelu 5P charakteristiky riadenia l'udských zdrojov 


\subsection{Stratégia podniku}

Podnik má v súčasnosti definovanú nasledujúcu víziu, politiku a ciele podniku:

Základnou víziou podniku je vytváranie hodnôt pre svojich klientov, zamestnancov a partnerov na základe etického a transparentného vzt’ahu. Vytváranie hodnôt pre zákazníkov a zamestnancov je závislé na dokonalom pochopení ich potrieb. Základnými hodnotami, ktorými chce podnik zefektívnit' svoje podnikanie, sú:

- zmysel pre služby zákazníkom,

- zmysel pre tímovú prácu,

- zmysel pre celkový rozvoj.

Medzi hlavné ciele podniku patrí neustále zdokonal'ovanie sa v poskytovaní služieb pre zákazníkov „ušitých na mieru“, znižovanie ceny týchto služieb, zvýšenie kvality a redukcia nákladov. Taktiež dôležitým ciel'om pre agentúru je disponovat' kvalitným a profesionálnym tímom pracovníkov. Podnik zdiel'a so svojimi klientami, zamestnancami a spolupracovníkmi celú radu spoločenských ciel’ov založených na vzájomnej dôvere, ktorá prispieva k jasným a lojálnym vzt’ahom.

Zásady správania sa podniku sú zahrnuté a vyjadrené v politike podniku, ktorá vyjadruje vzt'ah k zákazníkom, obchodným partnerom, zamestnancom a okolitej komunite. Základnými pravidlami, podl’a ktorých sa podnik riadi, sú:

- zákazník určuje konanie podniku,

- obchodný úspech = istota podniku,

- excelentné vedenie dosahuje efektívne výkony,

- stabilné obchodné vzt’ahy,

- $\quad$ rast výkonnosti = perspektíva,

- vedomie spoločenskej zodpovednosti.

\subsection{Analýza vonkajšieho a vnútorného prostredia}

Sledovaná marketingová a eventová agentúra pôsobí na slovenskom trhu od roku 2007, pričom v súčasnosti sa snaží rozšírit' svoje doposial' lokálne pôsobenie na celoslovenskú úroveň. Organizácia sídli v Žiline a hlavnými predmetmi činnosti sú:

- organizácia sút'aží a tanečných podujatí,

- organizácia kultúrnych podujatí pre obyvatel’ov mesta Žilina,

- vedenie tanečnej školy,

- prevádzka tanečného klubu,

- zhotovovanie www stránok,

- prekladatel'ské a tlmočnícke služby,

- prieskum trhu a verejnej mienky,

- fotografické služby,

- producentská činnost' v oblasti videotvorby.

Agentúra má celkovo dvadsat'šest' zamestnancov, z toho devätnást' žien a sedem mužov. Dvaja zamestnanci majú dosiahnuté základné vzdelanie, pätnást' zamestnancov má stredoškolské vzdelanie (dvanást' zamestnancov stredoškolské vzdelanie s maturitou) a devät' zamestnancov má ukončené vysokoškolské vzdelanie. Veková štruktúra zamestnancov nie je vel'mi rôznorodá. Najviac zamestnancov je vo veku od 21 - 30 rokov (13 zamestnancov), 8 zamestnancov má od 31 do 40 rokov a 5 zamestnanci majú menej ako 20 rokov.

Organizačná štruktúra agentúry je vel'mi neštandardná, dala by sa označit' ako plochá. Vedením podniku sa zaoberajú traja vrcholoví manažéri, pričom dvaja z nich sú majitelia, ktorí stáli pri jej zrode. Útvar riadenia l'udských zdrojov v agentúre nie je implementovaný, jednotlivými funkciami riadenia l'udských zdrojov sa zaoberá jeden zo spoločníkov a pomáhajú mu dvaja línioví manažéri. Agentúra plánuje pri definovaní stratégie riadenia l'udských zdrojov vytvorit' samostatný útvar, ked'že si uvedomuje dôležitost' zamestnancov 
a chce taktiež zaviest' nový systém hodnotenia zamestnancov. Daný útvar by mal mat' na starosti jeden z líniových manažérov, ktorí aj v súčasnosti pomáhajú majitel’ovi.

Vonkajšie prostredie, ktoré vplýva na podnik, sa skladá z dvoch sfér - makroprostredia a odvetvového prostredia. Makroekonomické prostredie pôsobí na podniky pozitívne, trh sa čiastočne dostal z recesie spôsobenej hospodárskou krízou, v poslednom roku sú ale podniky a živnostníci postihnutí legislatívnymi zmenami, najmä zavedením daňovej licencie, ktorá sa pohybuje v rozmedzí od 480 do 2880 Eur. Taktiež vzdelanostná úroveň v Slovenskej republike rastie, podnik ale na obsadenie nového pracovného miesta hl'adá schopných a talentovaných pracovníkov s chut'ou pracovat' s l'ud'mi bez ohl'adu na ich dosiahnuté vzdelanie.

V Žilinskom kraji nemá agentúra takmer žiadneho konkurenta, ktorý by poskytoval služby v podobnom rozsahu. Agentúra spája predovšetkým činnosti eventovej a marketingovej agentúry, tanečnej školy a okrem toho vlastní priestory priamo v centre mesta, kde prevádzkuje tanečný klub, a ktoré využíva pri organizácii rôznych kultúrnych podujatí. $Z$ dodávatel'skej perspektívy je podnik závislý od dodávatel'ov nápojov a surovín potrebných pre fungovanie tanečného klubu a od DJov, ktorých objednáva na každú akciu samostatne. Zákazníkmi podniku sú najmä mladí l’udia, návštevníci tanečného klubu a tanečnej školy a kultúrnych podujatí organizovaných pre mesto Žilina. Ďalšími odberatel'mi sú podniky, ktoré využívajú služby zhotovenia www stránok, prekladatel'ských činností a prieskumu trhu a verejnej mienky.

\subsection{Strategické potreby podnikania}

Aby podnik mohol uskutočnit' vybranú stratégiu, mal by sa zamerat' na neustále zdokonal'ovanie sa v poskytovaní služieb pre zákazníkov „ušitých na mieru“ a disponovat' kvalitným a profesionálnym tímom pracovníkov. Najdôležitejšími funkciami riadenia l'udských zdrojov sú teda získavanie a výber zamestnancov, adaptácia zamestnancov a vzdelávanie zamestnancov.

Podnik získava zamestnancov $\mathrm{z}$ interných aj externých zdrojov. Ak sa rozhodne obsadit' vol'nú pracovnú pozíciu z externého zdroja, vyberie zoznam médií, kde správu o vol'nom pracovnom mieste zverejní. Interný nábor uskutočňuje medzi svojimi zamestnancami prostredníctvom oznamov a pri tímových stretnutiach. Zamestnanci môžu taktiež odporúčat' kandidátov na vol'né pracovné miesto. Ak takto získaný pracovník zostane pracovat' v podniku dlhšie ako 6 mesiacov, zamestnanec, ktorý ho odporučil, získa hodnotný darček.

Výberový proces sa v podniku uskutočňuje prostredníctvom výberového pohovoru. Pohovor vedú vrcholoví manažéri s líniovým manažérom, ktorý sa spolupodiel'a na riadení l'udských zdrojov. Pre podnik sú najdôležitejšie schopnosti kandidáta, nie jeho vzdelanie. Novému pracovníkovi sú po nástupe do agentúry predstavené hodnoty podniku, jej zvyklosti a fungovanie pracovnej evidencie. Adaptáciu nového zamestnanca má na starosti líniový manažér.

Proces vzdelávania zamestnancov sa skladá zo štyroch fáz: identifikácia potreby vzdelávania $\rightarrow$ plánovanie vzdelávacieho procesu $\rightarrow$ realizácia procesu $\rightarrow$ vyhodnotenie efektivity. Všetky semináre a školenia sú prispôsobené individuálnym potrebám zamestnancov, ked’že vzdelávanie sa v agentúre považuje za jednu z najdôležitejších činností riadenia l'udských zdrojov. Využívajú sa nasledovné spôsoby vzdelávania:

- sebavzdelávanie,

- mentorovanie,

- hl'adanie informácie prostredníctvom internetu,

- videokonferencie,

- rotácia na pracovisku,

- prednášky a semináre. 
Za najefektívnejšiu metódu vzdelávania považujú zamestnanci videokonferencie a rotáciu na pracovisku. Pre splnenie celopodnikovej stratégie by sa mala agentúra zamerat' na štyri najdôležitejšie funkcie riadenia l'udských zdrojov: získavanie a výber zamestnancov, adaptácia zamestnancov a vzdelávanie zamestnancov, pričom by mala vediet' identifikovat' talentovaných zamestnancov s vysokým potenciálom pre kariérny rast a zabezpečit' im možnosti rozvoja schopností a vedomostí.

$\mathrm{Na}$ základe predchádzajúcich krokov definujeme konečné štyri kroky modelu 5P: filozofiu riadenia l'udských zdrojov, politiku riadenia l'udských zdrojov, programy, praktiky a procesy riadenia l'udských zdrojov. Vychádzame zo strategických potrieb podniku a analýzy vonkajšieho a vnútorného prostredia.

\subsection{Filozofia riadenia l'udských zdrojov}

Podnik vníma zamestnancov ako najcennejšie imanie, prostredníctvom ktorého môže vytvárat' hodnoty a zefektívnit' svoje podnikanie. Podnik chce vytvorit' tím zamestnancov, ktorý sa bude ctižiadostivo a lojálne podiel'at' na dosahovaní konkurenčnej výhody podniku a maximalizovaní zisku.

\subsection{Politika riadenia l’udských zdrojov}

Politika riadenia l'udských zdrojov definuje hodnoty, ktoré by zamestnanci mali dodržiavat' pri dosahovaní ciel'ov podniku. Vychádzajúc z celkovej politiky podniku, zamestnanci by sa mali riadit' nasledovnými hodnotami:

- dodržiavanie vysokej úrovne zákazníckych služieb,

- snaha o získanie obchodného úspechu,

- excelentné vedenie podniku,

- snaha o udržanie stabilných obchodných vzt’ahov,

- podiel na spoločenskej zodpovednosti podniku.

\subsection{Programy riadenia l'udských zdrojov}

Programy riadenia l'udských zdrojov alebo stratégia riadenia l'udských zdrojov koordinujú úsilie tým, že adresujú hlavné problémy vzt'ahu l'udia - podnik. Víziou riadenia l'udských zdrojov vybranej agentúry je vytvorenie profesionálneho tímu zamestnancov so zmyslom pre celkový rozvoj podniku, ktorý dokáže vyhoviet' nielen komplexným, ale najmä individuálnym požiadavkám zákazníkov. Víziu možno dosiahnut’ prostredníctvom splnenia nasledujúcich ciel'ov:

- Prijímat' schopných zamestnancov, ktorí sú stotožnení s filozofiou podniku.

- Rozvíjat' talent súčasných zamestnancov prostredníctvom vzdelávacieho procesu.

- Rozvíjat' tímový duch prostredníctvom kolektívnych akcií mimo podniku.

- Motivovat' zamestnancov k lepšej starostlivosti o zákazníkov.

- Rozšírit' vzdelávací proces o jazykové kurzy a kurzy asertivity.

\subsection{Praktiky a procesy riadenia l'udských zdrojov}

Praktiky a procesy riadenia l'udských zdrojov predstavujú konkrétne postupy a aktivity pre všetky roly vedenia, riadenia a operačné roly. Ich úlohou je motivovat' do potrebného správania v rolách. Vyzdvihli by sme nasledujúce praktiky:

- Adopcia stratégie riadenia l’udských zdrojov vrcholovým vedením organizácie.

- Nábor a výber zamestnancov podl'a manažmentu talentu.

- Systém hodnotenia výkonnosti, štandardy výkonnosti pre schopných a talentovaných jednotlivcov.

- Identifikácia potrieb a návrh metód pre vzdelávanie zamestnancov so zameraním sa na talentovaných jednotlivcov.

- Vzdelávanie všetkých zamestnancov vo vzt'ahu k dosahovaniu ciel'ov podniku.

- Metódy rozdel'ovania zdrojov z aspektu talentovaných jednotlivcov. 
- Vypracovanie a implementácia metód angažovanosti jednotlivcov.

- Využitie kreatívnych skupinových metód pri rozvíjaní tímového ducha a dobrých vzt'ahov na pracovisku.

\section{Závery a odporúčania}

Sledovaná marketingová a eventová agentúra pôsobí zatial' na lokálnom trhu, kde disponuje konkurenčnou výhodou v podobe takmer nulovej konkurencie. Ak chce ale pôsobit' celonárodne, musí sa zamerat' na rozvoj zdrojov, ktoré jej dokážu zabezpečit' dlhodobú konkurenčnú výhodu a prosperitu. Týmto zdrojom je l’udský kapitál, čiže všetci zamestnanci podniku. Prostredníctvom modelu 5P sme definovali súčasný stav riadenia l'udských zdrojov a strategického riadenia podniku a následne navrhli hlavné komponenty strategického riadenia l'udských zdrojov (filozofiu, politiku, programy, praktiky a procesy riadenia l'udských zdrojov). Podnik chce vytvorit' profesionálny tím zamestnancov, ktorý dokáže vyhoviet' všetkým požiadavkám zákazníkov. Pre naplnenie vízie a ciel'ov preto navrhujeme zamerat' pozornost' na manažment talentu, či pri nábore a výbere zamestnancov, alebo pri vzdelávaní a kariérnom rozvoji. Zamestnanci očakávajú viac možností kariérneho rastu, ktorý je možné riadit' prostredníctvom identifikovania schopných, talentovaných a predovšetkým pracovitých zamestnancov s vysokým potenciálom.

\section{Literatúra}

[1] SLÁVIK, Š.: Strategický manažment. Bratislava : Sprint dva, 2009. 403 S. ISBN 978-8089393-08-4.

[2] ČIHOVSKÁ, V., HASPROVÁ, M., MATUŠOVIČOVÁ, M.: Manažment l'udských zdrojov. Bratislava: Ekonóm, 2010. 226 s. ISBN 978-80-225-3021-7.

[3] KACHAŇÁKOVÁ, A.: Riadenie l'udských zdrojov: l'udský faktor a úspešnost' podniku. Bratislava: SPRINT, 2003. 212 s. ISBN 80-89085-22-9

[4] ŠUBÍKOVÁ, M.: Význam strategického riadenia l’udských zdrojov v dlhodobom napredovaní podniku služieb: bakalárska práca. Žilina: Žilinská univerzita v Žiline, 2014. $53 \mathrm{~s}$.

[5] STRENITZEROVÁ, M.: Pohlad expertov na strategické riadenie l'udských zdrojov v poštových podnikoch. In: POSTPOINT 2011: "Open market - a challenge for postal services" : 9. medzinárodná konferencia zástupcov poštových správ a univerzít, Rajecké Teplice, 19.-20. september 2011, zborník príspevkov. Žilina: Žilinská univerzita, 2011. s. 308-325. ISBN 978-80-554-0413-4.

[6] JANDZÍKOVÁ, K., STRENITZEROVÁ, S.: Návrh modelu strategického riadenia ludských zdrojov v Slovenskej pošte, a.s. In: IPoCC - International Postal and eCommunications Conference, Pardubice: 16.-17. záŕí 2010, sborník př́spevků mezinárodní konference IPoCC.. Pardubice: Institut Jana Pernera, 2010. ISBN 978-8086530-68-0. s. 147-156.

\section{Grantová podpora}

Príspevok je publikovaný ako súčast’ riešenia projektu č. 2/KS/2014 „Regulačné aspekty interoperability poštových systémov“" 